\title{
DAĞLIK KARABAĞ SORUNUNDA ULUSLARARASI ARABULUCULUK ${ }^{1}$
}

Yetkili Yazar | Correspondent Author: Büşra Öğüitçü

\section{International Mediation on the Nagorno Karabagh Issue}

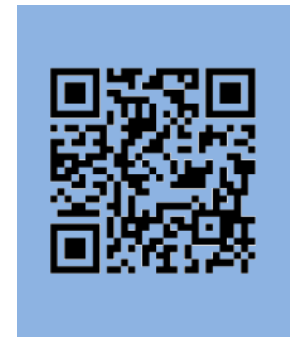

\section{Yazar(lar) | Author(s) Büşra ÖO $\breve{U} T C ̧ \ddot{U}^{2}$ \\ Muzaffer Ercan YILMAZ}

MAKALE BİLGÍSI
Makale Geliş Tarihi : 19/01/2021
Makale Kabul Tarihi : 18/02/2021
Anahtar Kelimeler:
Uluslararası Arabuluculuk,
Dağlık Karabağ Sorunu,
Arabuluculuk, Uluslararası
Çatışma Yönetimi,
Uluslararası Çatışma
Çözümü

\section{ARTICLE INFORMATION}

Submission Date $\quad: 19 / 01 / 2021$ Accepted Date $\quad: 18 / 02 / 2021$

Keywords:

International Mediation, The Nagorno-Karabagh Issue, Mediation, International Conflict Management, International Conflict Resolution

\begin{abstract}
Bu çalışma, Dağlık Karabağ sorunu özelinde, bir çatışma çözüm stratejisi olarak uluslararası arabuluculuk ve söz konusu stratejinin etkinliği üzerine analitik bir tartışma ortaya koymayı amaçlamaktadır. Dağlık Karabağ olarak anılan bölge üzerine Ermenistan-Azerbaycan çatışması, Soğuk Savaş sonrası dönemin en ciddi ve kanlı sorunlarından biri olmuştur. Sorunun devam etmesi, bölgesel güvenliği etkilediği kadar, mevcut veya yapılması planlanan enerji nakil hatlarının güvenliğini de tehlikeye atmaktadır. Çatışmanın açık bir biçimde ortaya çıktığı 1990'ların başlarından beri sorunun çözümü üzerine çok sayıda uluslararası arabuluculuk girişimi gerçekleşmiş, ancak bu girişimler üzerine detaylı bir bilimsel çalışma yapılmamıştır. Dolayısıyla bu çalışma, bu yöndeki boşluğu doldurmaya yönelik bir katkı ortaya koymayı amaçlamaktadır. Metodolojik açıdan tipik bir tek vaka analizi niteliğindeki çalışmada, ikincil verilerin yanı sıra, kartopu yöntemine dayalı olarak gerçekleştirilen röportajla elde edilen birincil verilere de yer verilmektedir. Çalışma, Dağlık Karabağ sorununun çözüm sürecinde başvurulan uluslararası arabuluculuğun etkinliği üzerine birtakım genel değerlendirmelerle son bulmaktadır.
\end{abstract}

\section{ABSTRACT}

This study aims to provide an analytical discussion on international mediation and its efficacy by looking through the mediation activities in the Nagorno Karabakh conflict. The conflict over Nagorno-Karabagh between Armenia and Azerbaijan has been one of the most serious and bloody conflicts in the post-Cold War era. The continuation of the conflict not only affects regional security but also energy security due to the existing pipelines or prospective pipeline projects. Many mediation initiatives have been implemented since the eruption of the conflict in the early 1990s but none of them have been studied systematically. Hence, this study tries to make a contribution to filling this gap. As for the method, the study utilizes secondary data, as well as primary data based on in-depth interviews and other relevant sources. The study ends up with many evaluations regarding the efficacy of international mediation used in conflict settings.

\footnotetext{
${ }^{1}$ Bu makale Büşra Öğütçü’nün Bursa Uludağ Üniversitesi Sosyal Bilimler Enstitüsü’nde devam etmekte olan "Barış İnşa Sürecinde Bir Çatışma Çözüm Stratejisi Olarak Uluslararası Arabuluculuk: Bosna Hersek ve Dağlık Karabăg Örnekleri” konulu doktora tez çalışmasından çıkarılmıştır.

${ }^{2}$ Araş. Gör., Uludağ Üniversitesi, İIBF, Uluslararası İlişkiler Bölümü, ORCID No: https://orcid.org/00000002-0773-1311, e-posta: busraogutcu@ gmail.com

${ }_{3}^{3}$ Prof. Dr., Uludağ Üniversitesi, İ̈BF, Uluslararası İlişkiler Bölümü, ORCID No: https://orcid.org/00000002-3938-0579, e-posta: muzafferercan@uludag.edu.tr
} 


\section{Giriş}

Çalışmada temel olarak, barış inşa sürecinde çözüm yöntemi olarak uluslararası arabuluculuk, Dağlık Karabağ örneği çerçevesinde incelenecektir. Bu minvalde ilk önce arabuluculuk süreci, kapsamı ve işleyişi incelenecektir. Daha sonra Dağlık Karabağ sorunu analiz edilecek ve sorun sürecinde arabuluculuk süreci değerlendirilecektir. $\mathrm{Bu}$ değerlendirme için temel kriter ise ilk etapta negatif barış olarak da nitelendirilen çatışmanın sona erip ermemesidir. Arkasından toplumlar arası barışı inşa etmek ve toplumların gelecekteki işbirliğine yönelik gelişmelere -bu da pozitif barış olarak nitelendirilmektedir- yönelik değerlendirilmeler yapılacaktır.

Çalışmada arabuluculuk kavramı ve işleyişinin incelenmesinin ardından Dağlık Karabağ sorununa yol açan süreç hakkında temel bilgiler verilecek, daha sonra Dağlık Karabağ sorunu sürecinde arabuluculuk girişimleri AGITT Minsk grubu incelenecek ve bu girişimlerin sonucu analize tabi tutulacaktır. Çalışmada röportaj tekniği kullanılacak süreç alanında yetkin kişilerle değerlendirmeye çalışılacaktır. Görüşlerine başvurulan uzmanlar çatışmanın taraf devletlerinden seçilmiştir çünkü süreci en iyi gözlemleyebilenlerin çatışmanın tarafları olduğu düşünülmektedir. $\mathrm{Bu}$ noktada Ermenistan tarafından kişilerle de röportaj yapılmaya çalışılmış fakat geri dönüş olmadığı için sadece Azerbaycan tarafından kişilerle röportaj yapılabilmiştir.

Çalışmanın temel araştırma sorusu uluslararası çatışmalarda arabuluculuk girişimlerini başarılı kılan temel koşullar ve altyapı nelerdir sorusudur. Çalışmada bununla bağlantılı olarak

- Arabuluculuk sürecinin avantajları ve arabuluculuğu diğer uyuşmazlık çözüm yöntemlerinden ayıran özellikleri nelerdir?

- Dağlık Karabağ Sorununda arabuluculuk süreci nasıl işlemiştir?

- Söz konusu arabuluculuk girişimi/ girişimleri başarılı mıdır? gibi sorulara da cevap aranacaktır.

\section{Uluslararası Arabuluculuk}

Bir uluslararası uyuşmazlık ortaya çıktığı zaman ilk olarak bunu tarafların çözmesi beklenir, çünkü ideal olan tarafların kendi sorunlarını kendilerinin çözmesidir (Yılmaz, 2006:26). Esasında sorunun mahiyetini ve taraflar için ne ifade ettiğini de en iyi tarafların kendileri bilir. Ancak bazı sebeplerden dolayı her zaman bu mümkün olmaz. $\mathrm{Bu}$ nedenle taraflar üçüncü bir tarafin desteğine ihtiyaç duyabilirler. Bu noktada arabuluculuk çatışma çözümünde önemli bir araç olarak kullanılmakta ve genişlemekte olan bir çalışma alanı olarak ön plana çıkmaktadır (Wallensteen \& Svensson, 2014:315). 
Arabuluculuk siyaset bilimi, psikoloji işletme yönetimi gibi alanlarda eğitim alan öğrenciler ve bilim insanları tarafından çalışılmaktadır (Bercovitch \& Lee, 2003:2).

Arabuluculuğun uluslararası ilişkilerde bir alternatif uyuşmazlık çözüm yöntemi olarak kullanımının ulus-devlet süreciyle paralel olarak geliştiği söylenebilir (Fisher, 2001:160). Diğer taraftan II. Dünya Savaş1 sonrasında arabuluculuk girişimlerinin arttığ1Soğuk Savaş sırasında arabuluculuk örneği Soğuk Savaş sorasına kıyasla çok fazla görülmese de- müdahil olan aktör sayısının arttığı, uluslararası hükümet dışı örgütlerin yerine bölgesel örgütlerin etki alanını arttırdığı görülmektedir (Wallensteen \& Svensson, 2014: 317-318). Ayrıca gruplar arası seviyede arabuluculuk daha kurumsal bir geçmişe sahipken toplum seviyesinde arabuluculuk daha yeni bir konsepttir (Fisher R. J., 2001:159).

Arabuluculuk kelimesi köken olarak Latince ikiye bölmek anlamında "mediare" sözcügünden gelmektedir (Wall \& Lynn, 1993: 160). Arabuluculuk güncel olarak temellerini BM Şartı'ndan alsa da çok eski zamanlardan beri kullanılmaktadır. Bu duruma örnek olarak MÖ 4000'li yıllarda Çin'de, Antik Yunan'da ve Roma uygarlığında uyuşmazlıkların çözümünde arabuluculuk yönteminin kullanılması verilebilir (Żakowska, 2014: 74). Çin'de de Ming hanedanlığı döneminde bölgenin yaşlı insanlarının toplumda sorunları çözmek için teşvik edildikleri bilinmektedir (Wall \& Lynn, 1993:161). Arabuluculuk kültürünün, Yahudi, Hristiyanlık ve İslam kültüründe de yer aldığını söylemek mümkündür. Christopher W. Moore İncil'e atıfla bizzat Hz. İsa'nın Allah ile insanlar arasında arabulucu olarak tanımlandığını, Yahudilikte arabuluculuğun çok eski zamanlardan beri kullanıldığını, İslamiyetteki arabuluculuk kültüründe daha çok yaşlı insanlardan oluşan bir topluluğun arabuluculuk görevini ifa ettiğini belirmektedir (1996:20). Batı medeniyetinde sekülerizmin ivme kazanması ile beraber arabulucuların sayısında artış olmuştur (Moore, 1996:20). Uluslararası alanda arabuluculuk diplomasinin uzun süredir bir parçası olmasına rağmen çalışmalara yeni konu olmakta, ayrıca, ülke içindeki çatışmalarda arabuluculuğun geleneksel formlarının uzun süredir var olmasına rağmen araştırmalarda ağırlık daha yeni formlara verilmektedir (Fisher, 2001:163).

Arabuluculuk en temelde bir uyuşmazlığa üçüncü taraf müdahalesinin bir türü olarak tanımlanabilmektedir (Zartman \& Touval, 1996: 445). Arabuluculuk taraflar arasındaki bir uyuşmazlığa, taraflar üzerinde hukuki otorite sahibi olmayan ve tamamen gönüllülük temelinde taraflarca kabul edilebilir bir üçüncü partinin müdahalesine işaret etmektedir (Moore, 1996: 15-16). Bu üçüncü parti bir devlet, uluslararası örgüt veya bir kişi-devlette resmi görevi olmayan- olabilmektedir. Bu noktada Christopher W. Moore burada tarafların arabulucuyu kabulünün önemli olduğunu vurgulamaktadır, bu elbette tarafların arabulucuya tamamen biat etmesi şeklinde değil ancak arabulucunun getireceği 
farklı açılımları dikkate alma konusunda istekliliğe, gönüllülük ise özgür seçime işaret etmektedir (Moore, 1996:16).

Diğer taraftan arabuluculuk, çeşitli uluslararası aktörler tarafından uluslararası çatışmaların devletlerarası ve devlet içi seviyede idare edilmesi amacıyla yürütülen faaliyetlerdir (Cantekin, 2016:414). Arabuluculuk, Oran Young'a göre, uyuşmazlığa doğrudan taraf olmayan bir aktör tarafından, görüşen taraflar arasındaki bir veya daha fazla problemi çözmeyi amaçlayan ve sonunda uyuşmazlığın çözümü için şartların oluşmasını sağlamaya yönelik alınan önlemlerdir (Żakowska, 2014:76). Jacek Barcik ve Tomasz Srogoz'a göre ise arabuluculuk, taraflara bağımsız ve tarafsız bir arabulucunun da dahil olduğu bir iletişime başlama ve adil bir çözüm bulma imkânı verir ve tarafların uyuşmazlığa dair algılarını ve düşüncelerini fiziksel şiddet ve yasal otoriteye başvurmadan değiştirebilmektir (Żakowska, 2014:76).

William I. Zartman ve Saadia Touval ise arabuluculuğu uyuşmazlığa üçüncü parti müdahalesi olarak tanımlamıştır (Żakowska, 2014: 76). Viçenç Visas arabuluculuğun iletişim kurmak, bilgi almak, arabuluculuk kuralları oluşturmak, var olan problemleri ve tarafların gizli amaç/planlarını tanımlamak, amaçları yeniden oluşturmak, uyuşmazlığın çözümü için seçenek oluşturmak, anlaşma ve uzlaşıya ulaşmak gibi birçok aşamadan oluştuğunu belirtmektedir (Żakowska, 2014:77). Jacob Bercovitch ve Richard Jackson'a göre arabuluculuk; bağımsız üçüncü tarafın katılımı ile görüşmelerin sürdüğü, karşıt tarafların yardım aradığı veya dışarıdan bir yardımı kabul ettiği bir uyuşmazlık çözüm sürecidir (Żakowska, 2014:78).

Arabuluculuk süreci genellikle tarafların isteği üzerine başlamakta; uyuşmazlığa çözüm üretemeyen taraflardan birinin veya her ikisinin arabulucuya başvurması ile arabulucu sürece dahil olmakta ve arabulucu tarafları sorunun çözümüne katkı sunabileceklerine ikna ederek süreci başlatabilmektedir (Yılmaz, 2018: 137). Arabuluculuğun meslek haline geldiği toplumlarda profesyonel arabuluculuk kurumları, arabuluculuğun meslek haline gelmediği toplumlarda tarafların kabul edebileceği üçüncü kişi arabulucu olabilmekte; geleneksel toplumlarda büyük ölçüde yaşlıların, sosyal statü ve ekonomik güç sahiplerinin, güvenilir siyasilerin ya da sivil toplum liderlerinin gayrı resmi şekilde üçüncü parti olarak uyuşmazlıklarda devreye girdikleri söylenilebilir (Y1lmaz, 2018: 137). Arabulucunun hukuki otoritesinin olmaması taraflar üzerinde etki sahibi olmaması anlamına gelmemektedir. Arabulucunun taraflar üzerinde uzmanlık, statü, siyasal ya da ekonomik gücünden kaynaklı etkisi olmaktadır (Yılmaz, 2018: 137). Arabuluculuğun amacı uyuşmazlığın taraflarının algısını veya davranışını fiziksel şiddete başvurmadan veya yasal otorite devreye girmeden çözmektir (Żakowska, 2014: 78).

Arabuluculuğu diğer üçüncü parti müdahalelerinden ayıran ve daha tercih edilebilir bir çözüm stratejisi yapan özelliği ise doğrudan güç kullanımına dayanmaması 
ve tarafların birine yardım etmeyi değil, tüm tarafların kabul edebileceği bir çözüm amaçlamasıdır (Zartman \& Touval, 1996: 445). Nitekim arabulucunun uyuşmazlığın çözümüne yönelik önerdiği taslakların taraflar açısından herhangi bir bağlayıcı özelliği bulunmamaktadır (Żakowska, 2014:76). Diğer bir deyişle arabuluculuk sürecinde tarafların eşit muamele görmeleri ve sürecin gönüllük esasına dayanması, ayrıca çözüm, konusunda nihai kararın taraflara ait olması da arabuluculuğun ayırıcı yönlerindendir (Y1lmaz, 2018:135).

Diğer taraftan arabuluculuk süreci taraflar arasında bir iletişim oluşmasını sağlayarak tarafların birbirlerine dair algılarını değiştirmeye çalışmaktadır (Zartman \& Touval, 1985: 31-32). Ayrıca diğer olası çözüm yöntemlerine kıyasla maliyeti daha az bir yöntemdir (Bercovitch, 1991: 4). Sonuç olarak arabuluculuğun bir uyuşmazlığın çözümünde kullanılabilecek en az maliyetli ve en barışçıl yöntemlerden biri olduğu söylenilebilir (Bercovitch, 1991: 3).

\section{1. Arabuluculukta Motivasyon}

Bir sorunun veya uyuşmazlık konusunun çözümüne dair belli bir yöntemin ve stratejinin uygulanmasının belli bir beklenti sonucu olduğu söylenilebilir. Bu noktada bu beklentinin en temelde uyuşmazlığın taraflar açısından kendi çıkarlarına en uygun şekilde çözülebileceği beklentisi olabileceğini söylemek yanlış olmayacaktır. Elbette başka beklentiler de tarafları belli bir çözüm yöntemi kullanmaya teşvik etmiş olabilir. Diğer taraftan arabuluculukta tarafları ve arabulucuyu uyuşmazlık çözümünde arabuluculuk yöntemini kullanmaya yönlendiren belli başlı sebepler vardır. Arabulucunun motivasyonu:

- Uyuşmazlığın olumsuz etkisinden kaçınma,

- Taraflar üzerinde etki sahibi olma/var olan etkiyi güçlendirme,

- Maddi beklenti,

- Sosyal uyum motivasyonudur (Y1lmaz, 2018: 137-141).

Tarafların motivasyonu ise:

- Görüşmenin yapılamaması / kesintiye uğramış olması,

- İletişimin nicelik ve nitelik olarak zayıf olması,

- Uyuşmazlığın kompleks ve tarafların bunu algılama yeteneğinin zayıf olması,

- Tarafların kendi başlarına çözüm üretememeleri,

- Görüşmeyi engelleyen değer farklılıklarının olmasıdır. 


\subsection{Arabulucunun Kimliği ve Özellikleri}

Tarafların kendi iradeleri ile arabulucuya başvurdukları durumlarda arabulucunun kimliği sorun teşkil etmemektedir, ancak böyle bir başvuru yoksa arabulucunun kimliği tartışmalı hale gelmektedir. Arabulucu bir birey olabileceği gibi, uluslararası kurumlar ve organizasyonlar veya bir devlet de olabilir.

Literatürde arabulucunun kişisel özelliklerine dair belirli bir tanımlama olmasa da genel geçer olarak arabulucunun şu özelliklere sahip olması gerektiği söylenebilir (Y1lmaz, 2018:133-150).

- Sabirli olma

- Güvenilir olma

- Bilgi sahibi olma

- Tarafsiz olma

- Arabuluculuk kapasitesine sahip olma

- Başarılı bir görüşmeci olma

- Günah keçisi olmayı kabullenebilme

\subsection{Arabuluculuk Süreci}

Arabuluculuk süreci belirli aşamalarla ilerlemektedir. Burada kapsam itibarıyla bu aşamaların sadece isimleri belirtilecektir. Bu aşamalar ismen şu şekilde sıralanabilir (Y1lmaz, 2018:156-173).

1) Taraflarla ön kontak ve güvenilirlik sağlama

2) Uyuşmazlık ve taraflar hakkında bilgi toplamak

3) Planlama

4) İletişime geçiş

a) İletişim eksikliği ve duygusallıkla mücadele

i) Duygusal boşalımı cesaretlendirme

ii) Duygusal boşalımı bastırma

b) Taraflar arası güven tesisi

c) Uyuşmazlık konusuna giriş

5) İletişimin olgunlaşması ve formül arayışı

6) Tarafları ikna ve sonuca varma 


\subsection{Arabuluculukta Süre}

Arabuluculukta genel geçer bir süre sınırlaması yoktur. Arabuluculukta süre uyuşmazlığın niteliğine göre değişebilmektedir. Süre uyuşmazlık konusu taraflarca gereğince tartışılıp her iki tarafın da çıkarlarını gözetecek bir çözüm ortaya çıkıncaya kadar esnetilebilir. Ancak buna istisna olarak tarafların mutabık kaldıkları bir formül oluştuktan sonra arabulucunun anlaşma için öne sürebileceği zaman sınırıdır (Yılmaz, 2018: 174).

\subsection{Arabuluculukta Zamanlama (Ripeness)}

Arabuluculuk sürecinde uyuşmazlığa kimin müdahil olduğu kadar zamanlama yani arabulucunun ne zaman müdahil olması gerektiği önemli bir konudur. Arabulucu taraflar tarafından davet edildiyse zamanlamanın doğru olduğu varsayılabilir (Yılmaz, 2018: 158). Zamanlama konusunda asıl sorun arabulucuyu tarafları davet etmediği durumda yaşanmaktadır. Bu durumda arabulucunun müdahil olacağı an süreç açısından önem taşımaktadır. Çünkü uyuşmazlığın meydana gelişini müteakip planlanan arabuluculuk girişiminin başarı olma ihtimali azdır bunun nedenleri ise

- Tarafların sorun çözmedeki yetersiz olduklarını düşündürür;

- Taraflar erken müdahaleye şüpheci yaklaşırlar;

- Sonunda hedeflerine ulaşacaklarını düşündükleri için bir süre mücadele etmek isterler (Y1lmaz, 2018:160).

$\mathrm{Bu}$ konuda çalışan bilim insanlarınca arabulucunun taraflar arasındaki uyuşmazlığın “olgunluğa eriştiği” bir zamanda müdahil olması gerektiğin savunulmaktadır. Burada olgunlaşmadan kasıt, uyuşmazlığın tırmanarak taraflara ciddi şekilde zarar vermeye başlaması tamamen kendi hedeflerine odaklanan tarafların bir çözüme varma imkânının kalmamasıdır (Yılmaz, 2018: 158). Bu duruma günümüzde dikkat çeken bilim insanı I. William Zartman'dır. ${ }^{4}$ Ona göre olgunlaşmanın en önemli belirtisi zarar veren çıkmazlık halidir (hurting stalemate) (Y1lmaz, 2018:158). Zarar veren çıkmazlık hali tarafların uyuşmazlığı algılayış biçimlerini değiştirebilir ve rasyonel karar vermelerini sağlayabilir (Żakowska, 2014:83). Zartman ve Touval, zarar veren çıkmazlık halinin taraflardan birinin tek başına amaçlarına ulaşamayacağını, problemi çözemeyeceğini, çatışmayı kazanamayacağını fark etmesiyle başladığını belirtir (1996:452). Taraflar kendilerini bir zafere ulaşamayacakları ve çözümsüzlüğün her iki taraf için de rahatsız edici olduğunu, ayrıca, uyuşmazlıkta sıkışmış hissettiklerinde bir alternatif politika ve çıkış yolu aramaya başlarlar (Zartman \& De Sato, 2010: 5). Bu

\footnotetext{
4 Daha öncesinde ise 16. yüzyılda Guicciardini tarafından doğru mevsim "rigth season” adıyla kavramsallaştırılmıştır (Donduran, 2018:353).
} 
aşamada taraflar henüz kesin bir çözüm yolu tanımlayamasalar da müzakere yolu ile çözümün mümkün olabileceği kanaatine varırlar (Zartman \& De Sato, 2010: 6). Bu da çözüme yönelik bir yol haritası belirlemede yardımcı olacaktır. Zarar veren çıkmazlık hali şu durumları içerir:

- Uyuşmazlık maddesel ve ilişkisel olarak tırmanabileceği en üst noktaya tırmanmıştır.

- Taraflar belli bir süredir birbirlerine ciddi olarak zarar vermişlerdir ve bu durdurulmazsa zarar vermeye devam edeceklerdir.

- Taraflar arasında güç simetrisi vardır ve tek başlarına kazanacak güce sahip değildir.

- Mantık yerini duygusallığa ve intikam hissine bırakmıştır (Zartman \& Touval, 1996: 452; Y1lmaz, 2018:159).

Zartman, bu koşullar oluştuğunda uyuşmazlığın arabulucunun müdahalesine uygun hale geldiğini savunur, çünkü uyuşmazlık bu aşamaya geldikten sonra taraflarda da uyuşmazlığın çözümü için bir farkındalık oluşmaya başlamıştır (Yılmaz, 2018:159). Yine de taraflar prestij kaygısıyla hareket etmekte ve girişimde bulunmaktan çekinmektedirler. Zartman bu noktada zarar veren çıkmazlık halinin arabulucunun uyuşmazlığı çözmede işine yarayabileceğini belirtmektedir. Arabulucunun yapması gereken tarafları zarar veren çıkmazlık halinin oluştuğuna ikna etmektir (Zartman, 2015:481). Arabulucu bu noktada devreye girer ve tarafları zarar veren çıkmazlık halinin oluştuğuna ikna edebilirse sorunun çözümüne yönelik büyük katkı sunabilir. Arabulucu, böylelikle, tarafların taviz veren taraf olma kaygısını da engellemiş olacaktır. Bu aşamada önemli bir nokta da yıpranma sürecinin ne kadar devam edeceğidir. Elbette taraflar arası uyuşmazlığın bir savaş boyutuna gelmesi beklenmemelidir. Burada arabulucunun bir görevi de tarafları uyuşmazlığın olgunlaştığına ve yeteri kadar zarar gördüklerine ikna etmektir (Y1lmaz, 2018:160).

\subsection{Arabuluculuk Sürecinde Kültür Faktörü}

Kültürel farklılık aktörlerin düşünce yapılarını ve davranış kalıplarını etkileyecek seviyede farklı değer yargılarına sahip olmaları olarak tanımlanabilir (Y1lmaz, 2018:169). Taraflarla arabulucunun aynı kültürden olması, süreci kolaylaştırıcı bir etken olarak önemli olsa da bu her zaman mümkün olmayabilir. Kültürel farklılık hem taraflar arasında hem de taraflarla arabulucu arasinda olabilir. 


\section{a. Kültürel Farklılı̆̆ın Taraflarla Arabulucu Arasında Olduğu Durumlar}

$\mathrm{Bu}$ durumda taraflar aynı ya da benzer kültürü paylaşmakta, arabulucu farklı kültüre mensup olmaktadır. Bu durumda arabulucu "pasif arabulucu” görevi yerine getirmektedir. Arabulucu iletişimi düzenlemeye çalışmalı, zorunlu olmadıkça formül arayışına girmemeli, görüşlerini kabul ettirmeye çalışmamalıdır (Yılmaz, 2018: 170). Arabulucu tarafların kültürleri hakkında bilgi edinmeli ve iletişim kurarken bu bilgileri dikkate almalıdır (Yılmaz, 2018:171).

\section{b. Kültürel Farklılı̆̆ın Hem Taraflar Hem de Taraflarla Arabulucu Arasında}

\section{Olduğu Durumlar}

$\mathrm{Bu}$ durumda taraflar da arabulucu farklı kültüre mensup olmaktadır. Bu durumda da arabulucu daha çok yönlendirici fakat aktif bir rol oynamalıdır çünkü taraflar arasındaki mesajların net olarak iletilebilmesi için arabulucunun çabası önemlidir (Yilmaz, 2018: 171).

\section{c. Kültürel Farklılı̆̆ın Taraflar Arasında Olduğu Durumlar}

$\mathrm{Bu}$ durumda taraflar da farklı kültüre mensup olmakta, fakat bir tarafin kültürü arabulucu ile yakın veya aynıdır (Yılmaz, 2018:172). Bu durumda arabulucu tarafsızlık noktasında özellikle hassasiyet göstermeli ve kültürel olarak yakın olduğu tarafı kayırıyor gibi bir imaj çizmemeye dikkat etmeli, yabancı olduğu kültür hakkında bilgi edinmeli ve iletişim kurarken bu bilgileri dikkate almalıdır (Yılmaz, 2018:172).

\section{Dağlık Karabağ Sorunu'nun Tarihçesi}

Dağlık Karabağ Sorunu son yüzyılın en önemli sorunlarındandır. Ermenistan ve Azerbaycan tarafının bölge üzerindeki tarihsel iddiaları ise sorunun temelini oluşturmaktadır. Her iki taraf da bölgede eski olduğunu ve bölgenin kendilerine ait olduğunu iddia etmektedir. Bu çerçevede Azerbaycan, Rus hakimiyeti altında olduğu dönemde de Mondros Ateşkes anlaşması sonrası İngiliz egemenliği döneminde ve gerekse SSCB döneminde Dağlık Karabağ'ın Azerbaycan'a bağlı olduğunu iddia etmektedir. Ayrıca 12.01.1920 tarihinde imzalanan Paris Barış Anlaşmasıyla da bağımsız Azerbaycan'ın tanınmış ve Dağlık Karabağ'ın Azerbaycan'a bağlı kabul edilmiş olduğunu belirtmektedir (İşyar, 2004; Aslanlı, 2013: 45). Tarihte gerçekleşen nüfus sayımlarında da bölgedeki Azerbaycanlı nüfusun çoğunlukta olduğu iddia edilmektedir. Ermenistan ise Dağlık Karabağ'ın çok eski dönemlerden beri Ermenistan'a ait olduğunu Azerbaycan'ın ise sadece 1918 yılında Çarlık Rusya'nın dağılmasından sonra bölgede siyasi olarak egemenlik sağladığını iddia etmektedir (Kocharyan, 2016: 5). 
Taraflar arasında soruna yaklaşım tarzı açısından da fark olduğu görülmektedir. Ermeniler durumu bir self-determinasyon hakkı ve bağımsızlık sorunu olarak görürken Azerbaycan cenahı ise durumu terör ve toprak bütünlüğü çerçevesinden ele almaktadır (Maresca, 1996: 477). Bu çerçevede Azerbaycan'ın Dağlık Karabağ'ın kendi ordusu, kendi politikasını belirleyebileceği bir özerklikle de olsa Azerbaycan sınırları içerisinde kalmasını sağlamaya çalışmaktadır (Abushov, 2005: 7). Emeniler Dağlık Karabağ’ın haklı self-determinasyon talebinin Azerbaycan tarafından engellendiğini iddia etmektedir (Kocharyan, 2016: 4). Ermeniler bu noktada sorunun Ermenistan ve Azerbaycan arasındaki bir sınır sorunundan ibaret olmadığını dile getirmektedir (Vaserman-Gınat, 1994: 358).

Azerbaycan ile Ermenistan arasındaki ana sorun olan Dağlık Karabağ bölgesi, Küçük Kafkas dağlarının güney doğusundaki bölgede yer almakta olup tarihi Taş Devrine kadar gitmektedir (Makas, 1990: 7-9). Bu bölge 4400 metrekarelik alanı kapsamakta, eski Karabağ vilayetinin yaklaşık dörtte birini oluşturmaktadır (Özyılmaz, 2013:194). Azerbaycan ve Ermenistan arasındaki soruna ilişkin ilk çatışma 1905 Rus Devriminden sonra yaşanmıştır. Bir Azerbaycan kökenli kişinin Taşnak Cemiyetine mensup kişi veya kişilerce öldürülmesi üzerine çatışma başlamıştır (Aslanlı, 2013: 42). SSCB döneminde ise Güney Kafkasya haritasının çizilmesi zor olmuş ve Gürcistan-ErmenistanAzerbaycan'ın haritaları Dağlık Karabağ ve Nahçivan probleminden dolayı hemen çizilememiştir (Cornell, 1997: 2). 4 Temmuz 1923 tarihinde Sovyet Komünist Partisi'nin Kafkas Bürosu tarafından Dağlık Karabağ Ermenistan Sovyet Sosyalist Cumhuriyeti'ne bırakılmıştır. Ancak Azerbaycan temsilcisi Nerimanov'un karara yönelik protestosunun ardından, 7 Temmuz 1923 tarihinde Dağlık Karabağ’a özerk bölge statüsü tanınmış, Azerbaycan Sovyet Sosyalist Cumhuriyeti'ne bağlı Dağlık Karabăg Özerk Bölgesi (DKÖB) oluşturulmuştur (Taşkıran, 1995: 203).

İleriki dönemde çatışmalar sürse de bunlar SSCB çatısı altında kontrol altında tutulabilmiştir. Ancak SSCB'nin zayıflamaya başladığı 80'li yılların sonlarından itibaren Dağlık Karabağ'a yönelik Ermeni talepleri daha fazla gündeme gelmiştir. Dağlık Karabağ meselesinin bir uluslararası sorun halini alması ise 13 Şubat1988 tarihinde Dağlık Karabağ Ermenilerinin Lenin Meydanı'ndaki gösterileriyle başlamıştır. Bu gösteriler Moskova'ya bağımsızlık talebine ilişkin dilekçe götüren bir grup sanatçı ve yazarın dönüşüne göre planlanmıştır (Waal, 2014: 27-28). Buna mukabil Azerbaycanlılar da Şuşa'da gösteri düzenlemiştir. Bu gösterilerin ardından süreç, Karabağ’ın Ermenistan'a bağlanmak için gösterdiği çabalar, buna karşın Azerbaycanlıların aksi yöndeki çabaları ile devam etmiştir. Sonuçta süreç SSCB'nin dağılması ve bölge üzerinde kontrolünü de kaybetmesiyle başlayan çatışmalar üzerine uluslararası aktörlerin de dâhil olduğu bir çatışma halini almıştır. 
20 Şubat 1988 tarihinde Dağlık Karabağ Yerel Konseyi (110 Ermeni, 30 Azerbaycan Türkü üye olmak üzere toplam 140 üye) Azerbaycanlı üyeler katılmaksızın Karabağ' in Azerbaycan Sovyet Sosyalist Birliği Cumhuriyeti'nden ayrılarak Ermenistan Sovyet Sosyalist Birlik Cumhuriyeti’ne katılmasını onaylamıştır. Nitekim Ermenistan Yüksek Sovyeti de 15 Haziran 1988 tarihinde Dağlık Karabağ'ın Ermenistan'a bağlanması yönünde bir karar almıştır (Pokalova, 2014: 73). Azerbaycan ise SSCB anayasasının cumhuriyetlerin sınırlarının, cumhuriyetlerin rızası hilafina değiştirilemeyeceğini öngören 78. maddesi uyarınca kararın hukuki geçerliliğinin olmayacağını savunmuştur (İşyar, 2004:379). 1988 yılının haziran ayında merkezi hükümet ile yapılan görüşmelerde Dağlık Karabağ Özerk Bölgesi’nin Azerbaycan'a bağlı kalması koşuluyla otonom cumhuriyet haline gelmesi önerilmiş, bu durum Ermeni tarafınca kabul edilmemiştir (Melander, 2001:60).

12 Temmuz 1988 tarihinde Dağlık Karabağ Ermenileri DKÖB'ni özerk bölge statüsü ile sözde “Artshak Özerk Bölgesi” adıyla Ermenistan'a bağlandıklarını deklare etmişlerdir (İşyar, 2004: 383). Bu durum üzerine merkezi hükümet, özel oturum ile gelişmeleri değerlendirmiş ve olası sınır değişikliğinin mümkün olmadığına, bölgede ekonomik yatırım ve kültürel programların başlatılmasına, konuya dair incelemelerde bulunmak üzere bölgeye bir temsilciler heyetinin gönderilmesine karar vermiştir (İşyar, 2004: 383). Devam eden uyuşmazlık üzerine SSCB Komünist Partisi Merkez Komitesi, 12 Ocak 1989'da Karabağ'1 doğrudan Moskova'ya bağlı bir birim haline getirmiştir (İşyar, 2004: 384). 28 Kasım 1989 tarihinde Sovyetler Birliği Yüksek Sovyeti tarafından alınan kararla Dağlık Karabağ yeniden Azerbaycan'a bağlanmıştır (İşyar, 2004: 388). Bu kararda Dağlık Karabağ'ın yeniden Azerbaycan'a bağlanması, güvenlik güçlerinin bölgede bulunması, bölgedeki Ermenilerin hakları için gerekli düzenlemelerin yapılması koşuluyla öngörülmüştür (Aslanlı, 2001: 401). Dağlık Karabağ'ın yeniden Azerbaycan'a bağlanmasına müteakip 1 Aralık 1989 tarihinde Ermenistan tarafı, Dağlık Karabağ'ın Ermenistan'a bağlandığını ve Birleşik Ermenistan'ın kurulduğunu deklare etmiştir. Dağlık Karabağ Ulusal Konseyi ise Azerbaycan'dan ayrıldığını bildirmiştir. Bu durum Azerbaycan'ın tepkisini çekmiş, SSCB ise bu kararın geçerli olmadığını belirtmiştir (İşyar, 2004: 388).

SSCB'nin dağılma sürecinde taraflar arasındaki çatışma devam etmiş ve nihayetinde Dağlık Karabağ Ermenileri, cumhuriyetlerin birlikten ayrılma sürecini düzenleyen yasay1 ${ }^{5}$ öne sürerek Ermenistan ile birleşmekten vazgeçmiş, Eylül 1991'de bağımsızlığını ilan etme yolunu seçmiştir. Buna karşın Azerbaycan Sovyet Cumhuriyeti, Dağlık Karabağ’ın özerk statüsünü iptal etmiş, SSCB Anayasasını öne sürerek sürece

\footnotetext{
530 Nisan 1990 tarihli bu yasa ile bir referanduma dayalı olarak otonom birimlere ve birlikten ayrılan cumhuriyetlerin ülkesinde 'yoğun halde bir yerde yaşayan' etnik azınlıklara self determinasyon hakkı tanınmıştır (İşyar, 2004: 395).
} 
karş1 çıkmıştır. Ancak bölgede 10 Aralık 1991 tarihinde referandum yapılmış, sonuç Dağlık Karabağ'ın bağımsızlığından yana olmuştur (İşyar, 2004: 395; Carley, 1998:1). Şu da belirtilmelidir ki, bu süreçlerin hiçbirine Dağlık Karabağ’daki Azerbaycan Türkleri katılmamışlardır.

SSCB'nin dağılmasından sonra ise Azerbaycan ve Ermenistan'ın bağımsızlıklarını kazanmalarıyla, iki taraf arasında çatışmalar başlamış ve sorun uluslararası boyut kazanmıştır. Özellikle Azerbaycan ve Ermenistan'ın bağımsızlıklarını kazanıp uluslararası örgütlere üye olmalarıyla sorun uluslararası alana da taşınmıştır. Ermenistan, Dağlık Karabağ bölgesinde Azerbaycan'a karşı askeri üstünlük sağladıktan sonra bölge dışı yerlere yönelmiştir. Örneğin Dağlık Karabağ’ın güvenliğini sağlamak için Dağlık Karabağ çevresindeki rayonlar da ele geçirilmiş, diğer taraftan Nahçıvan'a da saldırılar düzenlenmiştir. Bu süreçte Ermenistan, Dağlık Karabağ ve etrafındaki Laçin, Kelbecer, Ağdam, Cebrail, Fuzuli, Gubadlı ve Zengilan rayonlarını işgal etmiştir. Taraflar arasındaki çatışmalar, 9 Mayıs 1994 tarihinde Bişkek Protokolü çerçevesinde, Azerbaycan ve Ermenistan Savunma Bakanları ile Karabağ Ermenileri temsilcileri arasında ateşkes ilanı ile durmuştur. Bu ateşkes anlaşmasının ardından çatışmalar ufak çapta devam etse de statüko uzun süre korunmuş, barış antlaşması yapma süreci arabulucuların katılımıyla devam etmiştir.

Ancak 27 Eylül 2020 tarihinde çatışmalar yeniden başlamasıyla, süreç yeni bir safhaya geçmiştir. Diğer ufak çaplı çatışmaların aksine taraflar bu defa kırk dört gün boyunca çatışmaya devam etmişler ve süreç içerisinde üç kez ateşkes (10 Ekim 2020, 18 Ekim 2020 ve 26 Ekim 2020 tarihlerinde) ilan edilse de ateşkesler, sadece, birkaç saat sürmüş ve taraflar çatışmaya devam etmişlerdir. Bu süreçte Azerbaycan 90'ların başındaki durumun aksine, Ermenistan karşısında açık askerî üstünlük sağlamış ve önemli toprak kazanımları elde etmiştir. 10 Kasım 2020 tarihinde ise taraflar bir ateşkes imzalayarak çatışmanın sona erdiğini açıklamışlardır. Anlaşmayı ilk duyuran lider, Ermenistan Başbakanı Nikol Paşinyan olmuş ve açıklamasında bu kararın kendisi ve Ermeni halkı için çok acı verici olduğunu, ancak bu kararı sahadaki gelişmeler sonrası askerî uzmanlarla görüşerek aldığını belirtmiştir (Washington Post, 2020). Azerbaycan Devlet Başkanı İlham Aliyev ise imzalanan anlaşma ile Dağlık Karabağ çatışmasına son verildiğini, anlaşmanın Ermenistan'ın yenilgisi anlamına geldiğini, Paşinyan'ın anlaşmayı kendi isteğiyle değil, Azerbaycan'ın “demir yumruğu” sayesinde imzaladığını belirtmiştir (Milliyet, 2020). Bu aşamada Azerbaycan'da sevinç gösterileri yapılırken Ermenistan'da protestolar olmuştur. Taraflar arasındaki anlaşmanın içeriğine bakıldığında:

- Azerbaycan ve Ermenistan askeri güçleri şimdiki pozisyonlarında kalacak; 
- Ermenistan'ın çekilmesine paralel olarak Rus barış gücü beş yıllığına bölgeye konuşlanacak, tarafların itiraz etmemesi durumunda görev süresi beş yıl daha uzatılacak;

- İşgal altındaki Azerbaycan topraklarından Kelbecer 15 Kasım, Ağdam 20 Kasım, Laçin ise 1 Aralık'a kadar Azerbaycan'a teslim edilecek;

- Anlaşmanın beşinci maddesi kapsamında bölgede hem Rus hem de Türk askerleri barış gücü görevinde bulunacak;

- Ulaşım, iletişimin kontrolü, Rusya Sınır Güvenlik Servisi kurumları tarafından sağlanacak;

- Dağlık Karabağ ve çevresinde yerlerinden edilmiş siviller, BM Sığınmacılar Yüksek Komiserliği gözetiminde evlerine geri dönecektir (BBC, 2020).

Anlaşmada Dağlık Karabağ statüsüne ilişkin bir statü tanımlanmamıştır.

\section{Dağlık Karabağ Sorunu’nda Arabuluculuk}

Dağlık Karabağ Sorunu sürecinde iki sütunlu bir arabuluculuk süreci işlemiştir. Bir yandan bölge devletlerinin arabuluculuk girişimleri, özellikle Rusya'nın çabaları, diğer taraftan ise AGİT Minsk Grubu nezdinde sürdürülen girişimler devam etmiştir. Süreçte AGİT Minsk Grubu'nun sunduğu planlar kabul görmezken, Rusya'nın daha etkin bir profil çizdiği söylenebilir. Son dönemde gelişen olaylarda ise Türkiye'nin daha aktif rol oynamaya çalıştı̆ğ gözlemlenmektedir. Bu çalışmada AGİT Minsk Grubu'nun İkinci Karabağ Savaş'ına kadar süren arabuluculuk faaliyetleri incelenerek değerlendirme yapılmıştır.

Çatışmalar devam ederken 24 Mart 1992 tarihinde Helsinki'de toplanan AGİK Dışişleri Bakanları Konseyi, Dağlık Karabağ sorununun çözümü için Azerbaycan, Almanya, ABD, Ermenistan, Beyaz Rusya, İsveç, İtalya, Fransa, Rusya, Türkiye, Çek ve Slovakya Federal Cumhuriyeti'nin dâhil olduğu "Minsk Grubu" teşkil etmiştir. Ayrıca AGİK, Minsk Grubu nezdinde bir kişisel temsilci de atamıştır (Hopmann, 2013: 17). 1997 yılında itibaren Fransa, Rusya ve ABD aynı zamanda grubun eş başkanları olarak görev yapmaktadır. Bu noktada belirtmek gerekir ki üç eş başkanlık yapan ülkede de Ermeni diasporasının olması Azerbaycan'ın sürece baştan temkinli yaklaşmasına neden olmuştur (Köremezli, 2011:265). Ayrıca ABD, Rusya, Türkiye, Azerbaycan, Ermenistan ve İtalya'dan oluşan 5+1 olarak ifade edilen bir çekirdek grup da vardır (Hopmann, 2013: 15). AGİK Minsk Grubunun temel hedefleri şunlardır:

- Çatışmanın çözümü için uygun ortam sağlamak;

- Ateşkesi sağlayıp Minsk Konferansını toplamak; 
- Barış güçlerinin görevlendirilmesini sağlayarak barışı desteklemek (Mosashvili, 2019: 112).

Minsk Konferansı'nın koordinasyonunu İtalya üslenmiş, konferansın Temmuz 1992'de Minsk'te yapılması kararlaştırılmış, ancak süreç başarısız olmuştur. BM ise bu çerçevede soruna müdahil olmama ve AGİT (Aralık 1992 tarihinde gerçekleşen Budapeşte zirvesinden sonra AGIK bu ismi almıştır) bünyesindeki çalışmaları desteklemeye karar vermiştir (Aslanlı, 2013:60). 20 Şubat 1993 tarihinde Roma'da Minsk Grubu Başkanı Mario Rafaelli’nin de katılığı Roma görüşmeleri başlamıştır. Görüşmede Azerbaycan, ABD, Ermenistan, Rusya temsilcileri yer almıştır. Bu görüşme sonucunda ortaya çıkan planda ise şu hususlar yer almıştır:

- Sürekli bir ateşkes sağlanacak;

- Ermeni kuvvetleri bölgeden çekilecek;

- Azerbaycan'1n uyguladığı ambargo kalkacak;

- AGİK gözlemcileri bölgeye gelecek (Milliyet, 1993).

28-29 Nisan 1993 tarihinde Roma'da gerçekleşen görüşmelerde, görüşmelerin devamı için Kelbecer'in boşaltılması koşulu öne sürülse de kabul edilmemiştir. 3 Haziran 1993 tarihinde taraflara Acil Eylem Planı sunulmuştur. Bu plan uyarınca 20 Haziran 1993 tarihine kadar Kelbecer' in boşaltılması tamamlanmalı ve temmuz ayı itibarıyla bölgeye AGİT gözlemcileri yerleştirilmelidir (Aslanlı, 2013:67). Plan Azerbaycan tarafından kabul edilse de Ermenistan Kelbecer'in boşaltılması için zaman istemiştir. 8 Eylül 1993 tarihinde taraflara yeniden Acil Eylem Planı sunulmuştur. Azerbaycan planın BM Güvenlik Konseyi'nin 853 sayılı kararına aykırı olduğunu iddia etmiştir.

AGİT Minsk Grubunun 1994 yılındaki ateşkesten sonra da sorunun kalıcı bir çözüme ulaşmak noktasında çabaları devam etmiş ve taraflara çeşitli planlar sunulmuştur. 1995 yılında AGITT Minsk grubunun Stokholm'de yapmayı planladığı toplantı görüşme şartlarının oluşmaması sebebiyle ertelenmiş ve AGİT Minsk Grubu Rus eş başkanı Vladimir Kazimirov taraflarla birebir görüşmüştür (Taşkıran, 2001: 129). 1996 Lizbon zirvesinde birtakım prensipler belirlenmiştir. Bu prensipler uyarınca Azerbaycan ve Ermenistan'ın toprak bütünlükleri tanınmış, Dağlık Karabağ’’n yasal statüsünün selfdeterminasyon ilkesi uyarınca belirlenmesi, Dağlık Karabağ ve nüfusu için güvenliğin garanti edilmesi belirtilmiştir (Pokalova, 2014: 74). Taslak Ermenistan hariç bütün taraflarca kabul edilmiştir. Azerbaycan bu noktada uzlaşma konusunda olumlu bir tavır sergilese de Dağlık Karabağ'ın kendi ordusu ve para birimi olmaması konusunda hassasiyet göstermiştir (Hopmann, 2013: 22).

AGİT Minsk Grubu 1997 yılında sorunun barışçll yollarla çözümü için sorunu daha bütüncül bir yaklaşımla ele alan bir taslak plan hazırlamıştır. Bu taslak plana göre Dağlık Karabağ'ın hukuki statüsü ve ateşkes durumu eş zamanlı müzakere edilecektir 
(Pokalova, 2014: 74). Bu çerçevede iki ayrı anlaşma metni hazırlanmıştır. Buna anlaşmalar uyarınca Ermenistan Dağlık Karabağ ve Azerbaycan arasında bir tampon bölge oluşturulması kararlaştırılmış, ancak bu plan Dağlık Karabağ temsilcileri tarafından kabul edilmemiştir (Pokalova, 2014: 75). Aralık 1997’te AGİT Minsk Grubu farklı olarak aşamalı bir yaklaşım belirlemiş ve buna yönelik bir plan hazırlamıştır. Bu plan uyarınca askerlerin geri çekilmesine müteakip Dağlık Karabağ, Azerbaycan ve Ermenistan arasında Dağlık Karabağ'ın gelecekteki durumunu belirlemek üzere ayrıca Laçin ve Şuşa konusunda görüşmeler başlamasına ilişkin karar alınacaktır (Pokalova, 2014: 75). Azerbaycan ve Ermenistan tarafından kabul edilmesine rağmen, plan Dağlik Karabağ tarafından kabul edilmemiştir.

1998 yılında AGİT Minsk Grubu tarafından taraflara bir plan daha sunulmuştur. Bu planda Rus Dışişleri Bakanı Yevgeny Primakov tarafından teklif edilen "Ortak Devlet” önerisi yer almıştır (Hopmann, 2013: 25). “Ortak Devlet” anlaşması uyarınca Dağlık Karabağ Azerbaycan sınırları içerisinde ortak bir devlet olarak yapılandırılacak, Laçin'in durumu ayrıca görüşülecek, kuvvet kullanımı reddedilecek, taraflar aşamalı olarak kuvvetlerinin geri çekilmesini tamamlayacaklardır (Pokalova, 2014: 75-76). Ancak bu öneri, Azerbaycan tarafından toprak bütünlüğünü ortadan kaldırdığ gerekçesiyle kabul edilmemiştir. 1999 yılında ABD Devlet Bakanlığı'ndan Kafkas uzmanı Paul Goble tarafından "Goble planı” oluşturulmuştur. Goble planında Laçin ile Meghri’nin değişimi öngörülmüştür (Güleç, 2015: 7). Fakat bu plan hayata geçmemiştir.

2001 yılında taraflar Key-West de görüşmüşlerdir. Bu görüşmelerde ilerlemeler sağlansa da anlaşmaya varılamamıştır. Bazı kaynaklara göre Key-West görüşmelerinde Azerbaycan Devlet başkanı Haydar Aliyev göçmenlerin dönüşü karşılığında Dağlık Karabağ'ın Ermeni kontrolünde kalmasını, ayrıca Nahçivan'dan Azerbaycan'a bir koridor açılmasını kabul etmiş, ancak iç kamuoyunda ağır eleştirilere maruz kalmıştır (Sienrukos, 2006: 5). 2003 yılında her iki ülkede de başkanlık seçimlerinin olması süreci yavaşlatmıştır. Key-West görüşmelerinin Azerbaycan açısından önemi görüşmelerde hazırlanan broşürde ilk kez Ermeni güçlerinin Azerbaycan topraklarını işgal ettiği ifadesinin geçmiş olmasıdır (İşyar, 2004: 656).

AGİT Minsk Grubu'nun bu çabalarından sonra 2004 yılında görüşmelerin Azerbaycan ve Ermenistan Dışişleri Başkanları arasında devam etmesini öngören Prag Süreci başlatılmış, süreç Robert Koçaryan ve İlham Aliyev arasındaki dört görüşme sonucunda başarıya ulaşamamıştır (Güleç, 2015: 8). Prag sürecinde ortaya konulan taslak planda Ermenistan'ın Azerbaycan'a ait yedi rayondan çekilmesi ve mültecilerin geri dönüşüne izin verilmesi, Ermenistan-Azerbaycan ve Ermenistan-Türkiye sınırlarının açılması, 10-15 yıl sonra Azerbaycan'da Dağlık Karabağ'ın statüsü için referandum yapılması öngörülmüştür (Lis, 2016: 18). 2007 yılında Madrid Prensipleri ortaya konulmuştur. Madrid Prensipleri Helsinki Nihai Senedinin güç kullanmama, toprak 
bütünlüğü ve eşit self-determinasyon hakkı gibi ilkelerine dayanmaktadır (Klever, 2013:5). Bu prensiplere göre aşamalı yaklaşım planlanmış, Dağlık Karabağ çevresinden askerlerin çekilmesi, Laçin ve Kelbecer için özel statü, Dağlık Karabağ' ’n statüsünü belirlemek için referandum öngörülmüştür (Güleç, 2015:8).

2009 yılında ise güncellenmiş Madrid Prensipleri çerçevesinde taraflar anlaşmaya varmak için uzlaşmışlardır (Pokalova, 2014: 75-76). Madrid Prensipleri'nin güncellenmiş halinde ise Dağlık Karabağ etrafindaki toprakların Azerbaycan'a bağlanması, Dağlık Karabağ için geçici bir statü oluşturulması, Dağlık Karabağ'ı Ermenistan'a bağlayacak bir koridor oluşturulması, Dağlık Karabağ'ın yasal statüsünü belirlemek için gelecekte bir anlaşma, göçmenler ve yerleri değiştirilmiş insanlar için evlerine dönüş hakkı ve barış operasyonları da dâhil güvenlik garantisi öngörülmüştür (Pokalova, 2014: 77). Madrid Prensipleri çerçevesinde 2011 yılındaki Kazan Zirvesinden de büyük beklentilere rağmen sonuç alınamamıştır.

\section{Dağlık Karabağ Sorununda Arabuluculuk Sürecinin Değerlendirilmesi}

Dağlık Karabağ Sorunu özelinde arabuluculuk süreci değerlendirilmeden önce cevaplanması gereken birtakım sorular bulunmaktadır. Bu başlık altında hem bu sorular Azerbaycanlı bilim insanlarıyla yapılan röportajlar çerçevesinde cevaplandırılmaya çalışılacak hem de arabuluculuk süreci Dağlık Karabağ Sorunu kapsamında değerlendirilecektir. Süreci değerlendirilmeden önce cevaplanması gereken sorular şunlardır:

- Dağlık Karabağ sorunu sürecinde arabuluculuk yapan aktörler doğru aktörler midir? Eğer aktörler yanlış ise hangi aktörler olabilirdi?

- Arabuluculuk girişimlerinin zamanlaması doğru muydu?

- Dağlık Karabağ sorunu sürecinde arabuluculuk çabaları yeterli midir? Yeterli değilse başka neler yapılabilirdi?

- Süreç barış inşası için gerçekten katkı sağlamış mıdır?

- Dağlık Karabağ sorununda adil bir arabuluculuk süreci işlediği söylenebilir mi?

İlk soru doğal olarak arabuluculuk yapan aktörlerin kimliğine yönelik olmuştur. $\mathrm{Bu}$ çerçevede Dağlık Karabağ Sorunu özelinde arabuluculuk sürecinin iki ayaklı olarak yürütüldüğünü söylemek mümkündür. Bu iki ayakta farklı aktörler arabulucu olarak yer almışlardır. Sürecin bir ayağında AGİT Minsk grubu ile uluslararası aktör bir arabulucu rolü üslenirken diğer taraftan Rusya başta olmak üzere Kazakistan ve İran gibi devletler arabuluculuk yapmışlardır. Arabuluculuk yapan aktörlerin doğruluğu noktasında Azerbaycan'dan farklı bilim insanlarının genel kabulü aktörlerin yanlış olduğu 
noktasındadır. Mevcut dış aktörlere özellikle ABD ve Rusya’ya yönelik bir güvensizlik söz konusudur. Örneğin Bakü Devlet Üniversitesi’nden Sevinç Ruintan bu konuda aktörlerin doğru olmadığını, arabuluculuk yapan ABD ve Rusya'nın sadece Dağlık Karabağ probleminin değil farklı coğrafyalarda farklı zamanlarda ortaya çıka "uzun süren" çatışmalara neden olan devletler olduğunu, problemin Azerbaycan ve Ermenistan arasında kendi gerçekliklerini göz önüne alarak sona erdirilmesi gerektiğini ve bu konuda her iki devlet başkanının üzerine çok ağır sorumluluk düştüğünü, eğer bir arabulucu gerekiyorsa bunun sadece bir devlet veya bir örgüt olması gerektiğini; bu devlet veya örgütün iki devleti sadece bir araya getirmesi, müzakerelerin ise sadece iki devlet arasında, müdahale olmadan yürütülmesini temin etmesi gerektiğini belirtmektedir. Arabulucu devlet olarak ise alternatif olarak Almanya'yı göstermekte, örgütlere ise bu noktada güven duymadığını belirtmektedir (Ruintan, 14.07.2020).

Yine Bakü Devlet Üniversitesi'nden Senuber İsmailova ise aktörlerin doğru aktörler olmadığını, ayrıca aktörler arasında Azerbaycan'ın çıkarlarını koruyan bir devlet olmadığını belirtmektedir. Türkiye'nin arabulucular arasında bulunmasının ise Azerbaycan'ın çıkarlarının korunmasında daha etkili olacağını düşünmektedir (İsmailova, 14.07.2020). Bakü Devlet Üniversitesi'nden Eldar Jafarov aktörlerin yanlış olduğunu ve arabuluculuk görevini BM, Rusya veya Türkiye'nin üstlenmesi gerektiğini belirtmiştir (Jafarov, 14.07.2020). Bakü Devlet Üniversitesi'nden Saida Quliyeva ise ekonomik alandaki baskıların daha önemli olduğunu ve bu noktada aktörlerin çok da fark1 olmadığını belirtmiştir (Quliyeva, 14.07.2020).

Faik Aliekberov ise aktörlerin doğru aktörler olmadığını, özellikle, Rusya Federasyonu'nun aktörler arasında bulunmasının yanlış olduğunu ve Türkiye'nin arabulucular arasında bulunması gerektiğini belirtmiştir (Aliekberov, 14.07.2020). Bakü Devlet Üniversitesi'nden Afet Qulaliyeva ise aktörlerin doğru olmadığını ve Fransa yerine Türkiye'nin arabuluculuk yapabileceğini belirtmiştir (Qulaliyeva, 14.07.2020). Bakü Devlet Üniversitesi'nden İqbal Agayev aktörlerin yanlış olduğunu ve arabuluculuk görevini İran, Rusya veya Türkiye'nin üstlenmesi gerektiğini belirtmiştir (Agayev, 14.07.2020).

Bakü Slavyan Üniversitesi'nden Kemale Ruintan ise sürecin adaletli işlemesi için konunun iki devlete bırakılması gerektiğini, eğer gerekirse başka aktörlerin devreye girebileceğini ve en azından görüşülen dönem için arabulucunun gerekmediğini belirtmiştir. Kemale Ruintan, gerektiğinde tarafsız bir ülkenin görüşmeler için seçilebileceğini ve sorunun çözümü için öncelikle ortaya atılan suni sebepleri kabul edip üzerine eğilmesi gerektiğini ayrıca Uluslararası Adalet Divanı'nın da yardımcı olabileceğini düşündüğünü dile getirmiştir. Sorunun çözümü için gereken tüm araçların uluslararası hukukta mevcut olduğunu belirtmektedir (K. Ruintan, 14.07.2020). 
Giresun Üniversitesi'nden Ayten Mehmed ise aktörlerin doğru aktörler olmadığını, ayrıca aktörler arasında Fransa'nın yerine Almanya'nın olabileceğini belirtmiştir. Fransa iç siyasetinde Ermeni Diasporasının çok etkin olduğunu, Ermeni tezlerinin devlet düzeyinde kabul gördüğünü, bunun da arabulucunun tarafsızlık özelliğine gölge düşürdüğünü belirmektedir. Aynı şekilde ABD'de de Ermeni Diasporasının ve nüfuzunun etkin olduğunu ve bu nedenle yine tarafsızlık açısından sorunlu olduğunu dile getirmiştir. Ayten Mehmed, Rusya'nın ise bölge ülkesi olarak bölge güvenliği açısından süreçte doğrudan çıkarı olduğunu, Kolektif Güvenlik Anlaşması Örgütü çatısı altında Ermenistan'1n müttefiki olması sebebiyle arabulucu olamayacağını savunmaktadır (Mehmed, 14.07.2020).

Bakü Devlet Üniversitesi'nden Ayten Qurbanova da aktörlerin doğru aktörler olmadığını ve AGİT Minsk grubunun üç eş başkanının da problemin çözümünden ziyade, statükonun korunmasından yana olduklarını belirtmiştir. Qurbanova, Ermeni Diasporasının Fransa ve ABD'deki karar alma mekanizmasındaki etkisi ve Rusya'nın Ermenistan ile olan ilişkileri göz önüne alındığında Azerbaycan'ın çıkarlarını koruyacak bir arabulucu aktöre ihtiyaç duyulduğunun ve Türkiye'nin arabulucu aktörlerden biri olmasının Azerbaycan aleyhine olan süreçte adaletin kısmen de olsa sağlanmasına katkıda bulunabileceğini düşündüğünü ifade etmiştir (Qurbanova, 14.07.2020).

Bakü Devlet Üniversitesi'nden Rövşen Hatemov ise esasen Dağlık Karbağ sorunu diye bir sorunun söz konusu olmadığını, sorunun Ermenistan'ın Azerbaycan'ın topraklarının bir kısmını işgal etmesinden ibaret olduğunu belirtmiştir. Etnik faktörlerin öne çıkarılmasının işgali perdeleme amacına yönelik olduğunu dile getimiştir. Hatemov, sorunun BM çerçevesinden AGİT Minsk Grubu eksenine çekilmesinin hatalı olduğunu, çünkü AGİT Minsk grubunun etkisinin sınırlı olduğunu belirtmiştir. Hatemov, Tarihsel tecrübelerin Kafkasya bölgesindeki uyuşmazlıkların çözümünün, bölgede çıkarları olan aktörlerin uyuşmasından geçtiğini söylemiştir. AGİT Minsk Grubunun dini faktörler ve eşbaşkanı olan ülkelerde Ermeni Diasporasının etkinliğini sorunun çözümüne olan katkısına yönelik şüphe doğurduğunu ve bu noktada arabulucu olarak ise Türkiye'nin de dahil olmasının Azerbaycan için önemli olduğu, ancak Ermenistan'ın buna karşı çıkacağını belirtmiştir (Hatemov, 14.07.2020).

İkinci soru ise arabuluculuk girişimlerinin zamanlamasına yönelik olmuştur. Daha önce bahsedildiği üzere zamanlama arabuluculuğun başarısı için önemli bir faktördür, bu nedenle arabuluculuk yapacak aktör zamanlamayı da dikkate almalıdır. Bu arabulucuya tarafların uzlaşmaya hazırlık durumu ile ilgili ipucu da verecektir. Dağlık Karabağ Sorunu özelinde 1994 yılındaki ateşkes temel alındığında, henüz çatışmanın olgunluk aşamasına erişmediği ve zarar veren çıkmazlık halinin oluşmadığı görülmektedir. Bu noktada taraflar hala kazanan olmayı hedeflemekte ve ulusal amaçlarına ulaşabileceklerini düşünmektedirler. Dağlık Karabağ'ın her iki taraf devlet için de önemi göz önüne 
alındığında tarafların kısa sürede uzlaşmaya yanaşmayacakları, sorunu kendi çıkarları çerçevesinde çözmek istemeleri ve taviz vermeye yanaşmamaları öngörülebilir. Zaten ateşkesin devamında nihai bir anlaşmanın ortaya çıkmaması da çatışmanın olgunluğa ulaşmadığını ve zamanlama noktasında sıkıntı olduğunu göstermektedir. Diğer taraftan çatışmanın 2020 yılının Ekim ayına kadar devam ettiği ve tarafların açıklamaları dikkate alındığında çatışmanın hale olgunluk noktasına ulaşmadığı söylenebilir.

Azerbaycan'dan farklı bilim insanlarının zamanlamaya dair algısının genel olarak olumsuz olduğunu söylemek mümkündür. Genel olarak zamanlama için ya çok geç kalındığını ve bunun Azerbaycan'ın aleyhine bir durum meydana getirdiğini veya sorunun taraflarının baş başa bırakılması gerektiğini belirtenler olmuştur. Az da olsa zamanlamanın doğru olduğunu düşünenler de olmuştur. Bu çerçevede Bakü Devlet Üniversitesi'nden Sevinç Ruintan 1990'ların başında Azerbaycan ve Ermenistan'ın SSCB'den yeni ayrılmaları sebebiyle doğru kararlar veremeyeceklerine ikna edildiklerini, o zaman için bunun belki doğru görünebileceğini, ama esasen yanlış karar olduğunu belirtmiştir. Sevinç Ruintan, biribirleri ile savaşmakta olsalar bile, iki devletin anlaşmasının beş devletin anlaşmasından daha kolay olabileeğini ve arabulucu devletlerin de çıkarlarının dikkate alınmasının kendisine göre, sorunu çıkmaza sokan nedenlerden biri olduğunu dile getirmiştir (Ruintan, 14.07.2020).

Bakü Devlet Üniversitesi'nden Senuber İsmailova ise arabuluculuk girişimleri için zamanlamanın doğru olmadığını, o dönem içerisinde SSCB tarafından hatalı müdahalelerde bulunulduğunu arkasından Rusya ve Kazakistan tarafindan devam eden arabuluculuk girişimleri ile paralel olarak Azerbaycan ve Ermenistan'ın AGíT üyeliği ile AGİT Minsk Grubunun yaratıldığını ve bu aşamada girişimin bir faydası olmadığını belirtmiştir (İsmailova, 14.07.2020). Bakü Devlet Üniversitesi'nden Afet Qulaliyeva da arabuluculuk için zamanlamanın doğru olmadığını düşündüğünü belirtmiştir (Qulaliyeva, 14.07.2020). Aliekberov da arabuluculukta zamanlama açısından doğru hareket edilmediğini belirtmektedir (Aliekberov, 14.07.2020). Bakü Devlet Üniversitesinden Saida Quliyeva da arabuluculuk için zamanlamanın doğru olmadığını düşündüğünü belirtmiştir (Quliyeva, 14.07.2020).

Giresun Üniversitesi'nden Ayten Mehmed ise zamanlama açısından bir problem olmadığını, arabuluculuk için zamanlamanın doğru olduğunu ifade etmiştir (Mehmed, 14.07.2020). Bakü Devlet Üniversitesinden Eldar Jafarov arabuluculuk girişimleri için zamanlamanın doğru olmadığını, zaman kaybedildiğini ve arabulucuların kendi çıkarlarını düşündüklerin belirtmiştir (Jafarov, 14.07.2020). Bakü Devlet Üniversitesinden Rövşen Hatemov ise uluslararası kuruluşların sorunun çözümü için arabuluculuk girişimlerinin, SSCB'nin dağılmasından ve Azerbaycan ve Ermenistan'ın AGİT’e üye olmasından sonra başladığını, çatışmanın ise 1988 yılında başladığını bu 
nedenle de girişimlerin çatışmayı ve yaşanan insani felaketleri önlemede yetersiz kaldığını belirtmiştir (Hatemov, 14.07.2020).

Bakü Slavyan Üniversitesi'nden Kemale Ruintan ise tarafların tecrübesiz olduğunu ve dış müdahalelerle çatışmanın tırmandırıldığını, bu noktada arabuluculuk için doğru zamanlama olmadığını, ayrıca aktörlerin hem birebirlerinden çekindiğini hem de bu sorunu kendi lehlerine firsata çevirmelerine izin vermemeye çalıştıklarını belirtmiştir (K. Ruintan, 14.07.2020). Bakü Devlet Üniversitesinden Ayten Qurbanova arabuluculuğun zamanlama açısından başarılı olsa da girişimlerin somut neticesinin ortaya çıkmamasının süreci önemsizleştirdiğini belirtmiştir (Qurbanova, 14.07.2020). Bakü Devlet Üniversitesinden İqbal Agayev de arabuluculuk için zamanlamanın doğru olmadığını düşündügünü belirtmiştir (Agayev, 14.07.2020).

Üçüncü soru Dağlık Karabağ sorunu sürecinde arabuluculuk çabalarını yeterliliğine ve yeterli değilse başka neler yapılabileceği üzerine olmuştur. Bu çerçevede Bakü Devlet Üniversitesi'nden Sevinç Ruintan arabuluculuk çabalarını yeterli olmadığını sadece boşuna zaman ve para kaybı olduğunu, Azerbaycan halkının aldatılmasına devam edildiğini, yapılması gerekenin çok kolay ve doğru olan bir yol olduğunu, bunun da uluslararası hukuk ilkelerine uyulması olduğunu belirtmiştir. Ruintan, her iki devlet ve halkın uluslararası hukuk ilkelerini kabul etmek durumunda olduğunun farkında olduğunu dile getirmiştir. Ruintan, uluslararası ilişkilerde çifte standartlar politikasının mevcut olduğu da dikkate alınırsa, problemin çözüm yolunun ABD ve Rusya arasında uzlaşmadan geçtiğini ve Azerbaycan'ın da bu iki devletle ilişkilerinde daha dikkatli olması gerçeğinin kabul edilmesi gerektiğini ifade etmiştir. Azerbaycan açısından ise yapılması gerekenin, Azerbaycan'da “devlet-halk” ilişkileri daha da güçlendirilmesi, karşılıklı itimadın daha da artırılması ve bu sayede hiçbir devletin veya gücün Azerbaycan'a içten "böl ve yönet” politikası uygulamakla onun çıkarlarına zarar vermemesin engellenmesi olduğunu belirtmiştir (Ruintan, kişisel iletişim, 14.07.2020).

Bakü Devlet Üniversitesi'nden Afet Qulaliyeva ise arabuluculuk çabalarının yeterli olmadığını ve sürecin çifte standarttan uzak olması gerektiğini belirtmiştir (Qulaliyeva, 14.07.2020). Faik Aliekberov arabuluculuk çabalarını yeterli olmadığını düşündüğünü ifade etmiştir (Aliekberov, 14.07.2020). Bakü Devlet Üniversitesi'nden Eldar Jafarov ise arabuluculuk çabalarının yeterli olmadığını; ilave olarak ise halklar arasında ilişkileri daha olumlu bir noktaya taşıyacak sürecin başlatılması, kamuoyunun öne çıkarılması gerektiğini belirtmiştir (Jafarov, 14.07.2020). Giresun Üniversitesi'nden Ayten Mehmed ise arabuluculuk çabalarını yeterli görmediğini ve arabulucuların değişebileceğini ifade etmiştir (Mehmed, 14.07.2020).

Bakü Devlet Üniversitesinden İqbal Agayev arabuluculuk çabalarının yeterli olmadığını ve yaptırımlardan istifade edilebileceğini belirtmiştir (Agayev, 14.07.2020). 
Bakü Devlet Üniversitesinden Ayten Qurbanova arabuluculuk çabalarının yeterli olmadığını tarafların çıkarlarını savunacak ve tarafsız devletlerden oluşan yeni bir arabuluculuk misyonunun oluşturulması ve bu aşamadan sonra görüşmelerin başarılı olması için yeni bir yol haritasının oluşturulması gerektiğini ifade etmiştir (Qurbanova, 14.07.2020). Bakü Devlet Üniversitesinden Saida Quliyeva arabuluculuk çabalarının yeterli olmadığını ve BM kararlarının uygulanması gerektiğini belirtmiştir (Quliyeva, kişisel iletişim, 14.07.2020).

Bakü Devlet Üniversitesinden Senuber İsmailova arabuluculuk çabalarının yeterli olmadığını AGİT Minsk Grubu'nun arabuluculuk yaptığı dönemde Azerbaycan topaklarının işgal edildiğini ve Ermenistan'ın BM Güvenlik Konseyi tarafından alınan kararlara uymadığını ayrıca AGİT Minsk Grubu'nun süreçten çekilmesi ve bunun yerine uluslararası kurumlar çerçevesinde bir çözümün daha doğru olacağını belirtmiştir (İsmailova, 14.07.2020). Bakü Slavyan Üniversitesinden Kemale Ruintan sorunun uzun zamandır hatta başlangıcından beri iki devlet arasında bir sınır sorunu olmaktan ziyade çıkar sorunu olduğunu, sorunun arabulucularının aynı zamanda sorunun tarafları olduğunu hatta neredeyse sorunun asıl muhatapları olan Azerbaycan ve Ermenistan'in arabulucu konumuna geldiğini bu nedenle de yeterli çabanın gösterildiğini düşünmediğini belirtmiştir (K. Ruintan, 14.07.2020).

Bakü Devlet Üniversitesi'nden Rövşen Hatemov ise AGİT Minsk Grubunun yirmi yıldan uzun bir süre sorunun masada çözülmesine yönelik çaba gösterdiğini, ama buna rağmen, Azerbaycan topraklarının beşte birinin işgal altında bulunduğunu, yüz binlerce kişinin mecburi olarak göç etmek zorunda kaldığını dile getirmiştir. Hatemov, bu duruma rağmen arabulucu aktörlerin çifte standart uyguladığını, bu nedenle AGİT Minsk Grubunun sürecin dışında kalması ve sorunun çözümünün BM çerçevesinde ele alınması gerektiğini, bu çerçevede Azerbaycan'ın işgal altındaki topraklarından tüm yabancı kuvvetlerin çekilmesi ve barış güçlerinin yerleşmesi gerektiğini belirtmiştir (Hatemov, 14.07.2020).

Yöneltilen dördüncü soru sürecin barış inşası için gerçekten katkı sağlayıp sağlamadığı konusunda olmuştur. Bu soruyla birlikte sürece katkıdan neyin anlaşılması gerektiğinin ortaya konulması gerekmektedir. Arabuluculuk sürecinden beklenen katkı çatışmanın durması ve negatif barışın sağlanması mıdır, yoksa barış inşasının gerçekleşmesi midir? Verilecek cevap da bu beklentiye bağlı olarak değişecektir. Dağlık Karabağ Sorunu özelinde durum incelendiğinde ise 1994 ateşkesi ile kısmi olarak negatif barışın sağlandığı söylenilebilir. Taraflar daha sonra ateşkesi ihlal etmiş olsa da önceki kadar şiddetli çatışmalar yaşanmamıştır. Pozitif barış ve barışın inşası noktasında ise sürecin henüz bir ilerleme kaydetmediği düşünülebilir. Gerek taraflar arasında bir barış anlaşması imzalanamamış olması ve gerekse tarafların birbirlerine dair düşünceleri göz önüne alındığında sürecin beklenilen somut bir katkı sunmadığı söylenilebilir. 
Diğer taraftan tarafların beklentisinin Dağlık Karabağ'ın kendi topraklarına ait olduğunun kabulü ve Karabağ'ın kendi sınırlarına dâhil edilmesi olduğu dikkate alınırsa sürecin her iki tarafın da beklentisini karşılamadığını söylemek mümkündür. Ermenistan açısından bakıldığında Dağlık Karabağ, uluslararası toplum tarafından Ermenistan toprağı olarak kabul edilmemektedir. Azerbaycan açısından bakıldığında ise Dağlık Karabă̆'daki Ermeni kontrolü devam etmekte ve süreç Azerbaycan'ın işgal altındaki topraklarının Azerbaycan'a geri verilmesini sağlayamamaktadır. Bu çerçevede röportajlarda genel olarak arabuluculuk sürecine bir güvensizlik beslendiği söylenebilir. Arabuluculuk sürecinin, sorunun çözümüne yönelik katkı sunmadığı ve sürecin Azerbaycan aleyhine olduğu yönünde bir kanı hakimdir. Özet olarak sürecin her iki taraf devletin de beklentilerini karşılamadığını söylemek mümkündür

Bakü Devlet Üniversitesi’nden Sevinç Ruintan sürecin barış inşası için gerçekten katkı sağlamadığını ayrıca, barış elde edilmesinin hedeflendiğini de düşünmediğini kendisine göre, hem "arabulucu" devletlerin hem de uluslararası örgütler sadece mevcut durumun daha da ağırlaşmamasına çalıştığını belirtmiştir (Ruintan, 14.07.2020). Faik Aliekberov sürecin barış inşası için gerçekten katkı sağlamadığını, durumun hep Azerbaycan'ın aleyhine geliştiğini belirmiştir (Aliekberov, 14.07.2020). Bakü Devlet Üniversitesi'nden Ayten Qurbanova sürecin barışa yönelik gerçekten katkı sağlamadığını aksine sorunun çözümünü geciktirdiğini savunmuştur (Qurbanova, 14.07.2020). Bakü Devlet Üniversitesi'nden Afet Qulaliyeva ise sürecin barış inşası için gerçekten katkı sağlamadığını düşündüğünü ifade etmiştir (Qulaliyeva, 14.07.2020).

Bakü Devlet Üniversitesi’nden Saida Quliyeva, sürecin barış inşasına yönelik gerçekten katkı sağlamadığını belirtmiştir (Quliyeva, 14.07.2020). Bakü Devlet Üniversitesi'nden Senuber İsmailova, sürecin barış inşasına yönelik somut bir katkı sağlamadığını düşündüğünü ifade etmiştir (İsmailova, 14.07.2020). Bakü Devlet Üniversitesi'nden Eldar Jafarov ise sürecin barışa yönelik gerçekten katkı sağlamadığını savunmuştur (Jafarov, 14.07.2020). Bakü Devlet Üniversitesi'nden İqbal Agayev sürecin barış inşasına yönelik somut bir katkı sağlamadığını aksine sürecin çatışmanın dondurulmasına yönelik bir çabayı andırdığını belirtmiştir (Agayev, 14.07.2020).

Bakü Slavyan Üniversitesi'nden Kemale Ruintan sürecin barış inşasına yönelik gerçekten katkı sağlamadığını, sorunun bölgenin jeostratejik ve jeoekonomik konumundan kaynaklandığını belirtmiştir (Ruintan, 14.07.2020). Giresun Üniversitesi'nden Ayten Mehmed sürecin barış inşasına yönelik gerçek katkı sağlamadığını belirtmiştir (Mehmed, 14.07.2020). Bakü Devlet Üniversitesi’nden Rövşen Hatemov ise Dağlık Karabağ Sorunu için yakın gelecekte adalaetli bir çözümün mümkün görünmediğini Azerbaycan'ın kendi imkânları ile sorunu çözmesi gerektiğini belirtmektedir (Hatemov, 14.07.2020). 
Yöneltilen beşinci soru arabuluculuk sürecinin adil işleyip işlemediği üzerine olmuştur. Bilindiği üzere arabuluculuk sürecinde adil bir yaklaşım sergilenmesi çok önemlidir. Taraflar süreçte adil bir yaklaşım algılamazlar ise sürece dair inançlarını kaybedecek ve anlaşma konusunda istekli olmayacaklardır. Tarafların adil bir arabuluculuk sürecinin işleyip işlemediğine yönelik inancının ilk aşaması için ise arabuluculuk misyonunu üslenen aktörlere güvenmeleri gerekmektedir. Arabulucu aktörün, bu anlamda, tarafların güvenini sağlamak için öncelikle her iki tarafa da eşit mesafede yaklaşması gerekmektedir. Ancak bu tarafsızlık mutlak anlamda tarafsızlık olarak algılanmamalıdır. Arabulucu aktör tarafların kendilerini eşit derecede ifade edebilecekleri bir ortam yaratmalı ve bu çerçevede kendini ifade etmekte zorlanmayan tarafa karşı kendini ifade etmekte güçlük yaşayan tarafın da görüşlerinin dile getirilmesi için gerektiğinde bu tarafa karşı teşvik edici olmalıdır. Arabulucu aktör ile taraflar arasında tarafsızlığa dair bu güven sorunu aşıldıktan sonra sürecin daha kolay işleyebileceği varsayılabilir.

Dağlık Karabağ Sorunu özelinde güven konusunda sürecin başından itibaren sorun yaşandığını söylemek mümkündür. İlk olarak arabulucu aktörlere karşı güvensizlik süreç açısından olumsuzluklara neden olmaktadır. Özellikle Azerbaycan açısından AGİT Minsk Grubu eş başkanı devletlerin iç siyasetinde Ermeni Diasporasının çok etkin olduğunun düşünülmesi bu aktörlere yönelik güvensizlik yaratmakta ve sürecin bir barış anlaşması imzalanmasına yönelik olası katkısını olumsuz etkilemektedir. Temelde arabulucu aktörlere karşı yaşanan bu güven sorunu sürece dair de kendisini göstermektedir. $\mathrm{Bu}$ durum adil bir arabuluculuk sürecine güvensizlik olarak da yansımaktadır. Özellikle Azerbaycan tarafında sürecin adil işlediğine yönelik ciddi soru işaretleri bulunmaktadır. Bu güvensizlik arabuluculuk sürecinin adil işleyip işlemediğine yönelik soruya verilen cevaplarda da görülmektedir. Soruyu cevaplayan bilim insanlarından çoğu arabuluculuk sürecinin adil işlemediğini düşündüğünü, sürecin hep Ermenistan lehine bir durum aldığını gerek arabulucu aktörlerin gerekse uluslararası toplumun Ermenistan'ın Azerbaycan topraklarındaki işgaline son veremediğini ve Ermenistan'in da bu durumu kendi lehine bir firsat olarak görüp kullanmaya devam ettiğini belirtmişlerdir. Bu durumda Azerbaycan'ın arabulucu aktörlere ve sürecin adaletine yönelik bu güvensizliğinin sorunun çözümüne ve barış inşası sürecine yönelik de bir engel oluşturabileceğini söylemek mümkündür.

Bakü Devlet Üniversitesi'nden Sevinç Ruintan, sorunun meydana çıktığı andan günümüze kadar yalnız ve yalnız büyük güçler arasında "nüfuz uğrunda çatışma” olduğu kanaatini dile getirmiştir. Ruintan, hiçbir süreçte adil yaklaşım olmadığını, tam tersine, sorunun ABD ve Rusya arasındaki ilişkilere bağlı olarak ya sakinleştiğini ya da gerginleştiğini ve çözülmesi için gerçekten hiçbir girişimde bulunulmadığını belirtmiştir (Ruintan, 14.07.2020). Bakü Devlet Üniversitesi’nden Afet Qulaliyeva arabuluculuk 
sürecinin adil işlediğini düşünmediğini belirtmiştir (Qulaliyeva, 14.07.2020). Bakü Devlet Üniversitesi'nden Ayten Qurbanova arabuluculuk sürecinin adil işlemediğini arabuluculuk misyonunu üslenen devletlerin ve büyük güçlerin isterlerse sorunun Azerbaycan'ın toprak bütünlüğü çerçevesinde çözülebileceğini ifade etmiştir (Qurbanova, 14.07.2020). Bakü Devlet Üniversitesi’nden Senuber İsmailova arabuluculuk sürecinin adil işlediğini düşünmediğini belirtmiştir (İsmailova, 14.07.2020). Faik Aliekberov arabuluculuk sürecinin adil işlediğini düşünmediğini belirtmiştir (Aliekberov, 14.07.2020).

Bakü Devlet Üniversitesi'nden Saida Quliyeva arabuluculuk sürecinin adil işlediğini düşünmediğini dile getirmiştir (Quliyeva, 14.07.2020). Bakü Devlet Üniversitesi'nden Eldar Jafarov ise arabuluculuk sürecinin adil işlemediğini süreçte tarafların çıkarlarının ön planda tutulması gerektiğini belirmiştir (Jafarov, 14.07.2020). Bakü Devlet Üniversitesi'nden İqbal Agayev arabuluculuk sürecinin adil işlemediğini, çünkü temelde arabuluculuk yapan devletlerin tarafsız olmadığını dile getirmiştir (İqbal Agayev, 14.07.2020). Giresun Üniversitesi’nden Ayten Mehmed de benzer şekilde, arabuluculuk sürecinin adil işlemediğini, çünkü temelde arabuluculuk yapan devletlerin tarafsız olmadığını belirtmiştir (Mehmed, 14.07.2020).

Bakü Slavyan Üniversitesi'nden Kemale Ruintan arabuluculuk sürecinin adil işlemediğini, sorunun çözümü için önce bölgeye yönelik özgün ulusal çıkarları olan aktörlerin kendi aralarındaki sorunları çözmeleri gerektiğini bu şekilde sorunun da kendiliğinden bir çözüm yoluna girebileceğini, diğer taraftan Azerbaycan açısından çatışmanın kuvvet kullanma yolu ile halledilmesinin de bir seçenek olduğunu bunun içinse gerekli hesaplamaların yapılması gerektiğini belirtmiştir (Ruintan, 14.07.2020). Bakü Devlet Üniversitesi'nden Rövşen Hatemov arabuluculuk sürecinin adil işlemediğini arabuluculuk rolünü üslenen aktörlerin uluslararası hukuka riayet etmediğini ve uluslararası güvenlik konusuna ciddi yaklaşılmadığını bu nedenle de uluslararası sistemin istikrarlı olmadığını savunmaktadır (Hatemov, 14.07.2020).

Röportajlarda görüldüğü üzere Azerbaycan tarafında aktörlere ve sürece yönelik ciddi kuşkular olduğu dikkati çekmektedir. İlk olarak, arabuluculuk yapan aktörlerin kimliğine yönelik ciddi kaygılar vardır. Rusya ve Fransa'ya yönelik güvensizlik göze çarpmakta ve bu çerçevede Türkiye'nin süreçte daha aktif olması beklenmektedir. Arabuluculuk girişimlerinin zamanlaması açısından ise yine genel olarak memnuniyetsizlik göze çarpmaktadır. Genel olarak arabulucuların Ermenistan'ın güçlü olduğu bir zamanda devreye girdikleri fakat esasen Azerbaycan ve Ermenistan'ı karşı karşıya/ baş başa bırakmaları gerektiği düşünülmektedir. Dağlık Karabağ sorunu sürecinde arabuluculuk çabalarını yeterliliği konusu da tartışmalıdır. Azerbaycan tarafı arabuluculuk çabalarını yeterli bulmamakta ve Azerbaycan'ın oyalandığını belirtmektedirler. Ayrıca toplumlar arasındaki ilişkilerin düzeltilme boyutunun eksik 
kaldığı da belirtilmektedir. Sürecin barış inşası için katkı sağlayıp sağlamadığı noktasında da genel olarak katkı sağlamadığı düşünülmektedir. Süreçte adil bir arabuluculuk işleyip işlemediği noktasında da cevaplar genelde olumsuz olmuş, Fransa ve Rusya'ya ilişkin kanaat sürecin de adil olmadığı algısını oluşturmuştur.

\section{Sonuç ve Değerlendirme}

Arabuluculuk sürecinin başarısının değerlendirmesi zor ve farklı bilim insanları değişik kriterler ortaya koymuş olsa da genel olarak, doğru aktörün/ aktörlerin arabuluculuk yapması, tarafların çözüme hazır ve istekli olması, müdahale zamanlamasının doğru planlanması, uyuşmazlı̆̆ın niteliğinin doğru analiz edilmesi, uyuşmazlığın niteliğine uygun doğru strateji geliştirilip uygulanabilmesi, konjonktürün iyi analiz edilmesi, arabulucunun taraflar üzerinde etki sahibi olması, sadece "peacemaking" (siyasi çözüm aşaması) ve "peace-keeping" (çatışmanın durması-negatif barış aşaması) aşamasına değil "peace building" (kalıcı barışın inşa edilmesi) aşamasına da önem vermesi ve buna yönelik girişimlerde bulunulması, arabuluculuk girişiminin başarılı olması için gereklidir. Bunlardan en kritik olanının "peace-making" ve "peacekeeping" aşamaları ile sınırlı kalınmayıp, "peace building” aşamasına da önem verilmesi olduğu söylenebilir, çünkü çatışan taraflar arasında asıl zihniyet dönüşümünü gerçekleştirecek olan budur.

Yukarıda sıralanan maddeler ve yapılan röportajlar uyarınca Dağlık Karabağ Sorununda arabuluculuğun başarısı değerlendirildiğinde ilk göze çarpan sürecin genel olarak "peace-making" ve "peace-keeping" aşamaları ile sınırlı kalıp "peace building" aşamasına yeterince önem verilmemesi olmaktadır. Otuz yıla yaklaşan arabuluculuk süreci, gerek tarafların birbirleri hakkındaki algısında gerekse sorunun çözümünde belirgin bir farklılık yaratmamıştır. Doğru aktörler noktasında ise yapılan röportajlarda en azından Azerbaycan tarafının, özellikle, Fransa noktasında ciddi tereddütleri olduğu ve tarafsızlık özelliği taşımadığı algısına sahip olduğu göz önüne alındığında soru işaretleri bulunduğu söylenilebilir. Süreçte tarafların çözüme hazır ve istekli olmamaları belki de en sorunlu alandır. Burada tarafların durumu sıfır toplamlı bir oyun olarak algılaması ve sorunu hayatî addedip karşılıklı uzlaşma fikrine uzak olmaları büyük rol oynamaktadır. Hâlbuki oyun taraflar açısından sıfır toplamlı olarak görülmese ya da tarafların bu algısını kıracak bir arabuluculuk süreci yönetilse daha farklı çıktılar elde edilebilir. Diğer bir koşul olan uyuşmazlığın niteliğinin arabulucular tarafından doğru anlaşılması noktası da sorunludur. Arabulucular soruna bölgesel/ küresel güvenlik, istikrar veya çıkar açısından bakarken taraflar açısından sorunun psikolojik ve duygusal karşılığı bulunmaktadır. Arabulucuların buna yönelik çalıştığı söylenemez. Arabulucular, uyuşmazlığın niteliğini tam olarak anlayamadıkları için buna uygun stratejinin geliştirilip 
uygulanabilmesi de mümkün olmamıştır. Uluslararası konjonktür açısından ise her aktörün, özellikle küresel aktörlerin bölgedeki rekabeti göz önüne alındığında, bölgeye yönelik farklı bakış açıları bulunduğundan bunu uyumlulaştırmak da mümkün olamamıştır. Arabulucular içerisinde yer alan aktörlerden Rusya'nın her iki taraf üzerinde de etkisi olduğu kabul edildiğinde bu açıdan en azından Rusya açısından etkinlik faktörünün sağlandığı söylenebilir. Tüm bu faktörler göz önüne alındığında Dağlık Karabağ sorununda arabuluculuk sürecinin istenen katkıyı vermediği belirtilmelidir.

Yukarıda sayılanlara ek olarak yaklaşık otuz yıl süren müzakereler sonucu ortaya en azından kalıcı bir ateşkesin ve ardından bir anlaşma metninin çıkamaması da (örneğin Bosna Hersek örneğinde Dayton Anlaşması gibi) sürecin sadece "peace building" aşamasında değil "peace-making" ve "peace-keeping" aşamalarında da sıkıntılar olduğunu göstermektedir. Ayrıca İkinci Karabağ Savaşı'nın ardından yapılan son anlaşmanın da uzlaşma ile değil bir tarafın (Azerbaycan'ın) sahadaki askerî üstünlüğünden sonra imzalanmış olması arabuluculuk sürecinin beklentiyi karşılamadı̆̆ını göstermektedir.

\section{Kaynakça}

Abushov, K. (2005). "The Nagorno Karabakh Conflict As A Part Of The "New" Eurasian Geopolitics”, Ankara Üniversitesi SBF Dergisi, 60(3), 1-32.

Aslanl, A. (2001). “Tarihten Günümüze Karabağ Sorunu”, Avrasya Dosyası,7(1), 393-430.

Aslanl1, A. (2013). Yeni Küresel Mücadelede Kafkasya ve Karabağ Sorunu, Ankara: EkoAvrasya Yayınları.

BBC. (2020). Armenia, Azerbaijan and Russia sign Nagorno-Karabakh peace dealPublished 3 hours ago. https://www.bbc.com/news/world-europe-54882564 (Erişim Tarihi:10.11.2020).

BBC. (10.11.2020). Dağlı Karabağ: Ermenistan Başbakanı Paşinyan Azerbaycan'la anlaşma için 'Halkımız için acı verici, kararı uzmanlarla görüşerek aldım' dedi, https://www.bbc.com/turkce/haberler-dunya-54882585 (Erişim Tarihi: 10.11.2020).

Bercovitch, J. (1991). "International Mediation", Journal of Peace Research Special Issue on International Mediation, 28(1), 3-6.

Bercovitch, J. \& Lee, S. (2003). "Mediating Internatıonal Conflicts: Examining The Effectiveness Of Directıve Strategies”, International Journal of Peace Studies, 8(1), 1- 17 . 
Cantekin, A. (2016). "Ripeness and Readiness Theories in International Conflict Resolution," Journal of Mediation and Applied Conflict Analysis, 3(2), 414-428.

Carley P. (1998). Nagorgno Karabakh: Searching for a Solution, A United States Institute of Peace Roundtable Report, https://www.usip.org/publications/1998/12/nagorno-karabakh-searching-solution (Erişim Tarihi: 17.04.2020).

Cornell, E. (1997). "Undeclared War: The Nagorno- Karabakh Conflict Reconsidered”, Journal of Asian and Middle East Studies, 20(4), 1-24.

De Waal, T. (2014). Karabağ: Barış ve Savaş süreçlerinde Azerbaycan ve Ermenistan, Didem Sone (Çev), İstanbul, Hrant Dink Vakfı Yayınları.

Donduran, C. (2018). Barış Çalışmaları (1. Baskı) içinde (342-375.), İstanbul: Adres Yayıncilık.

Fisher, R. J. (2001). Methods of Third-Party Intervention, https://www.berghoffoundation.org/fileadmin/redaktion/Publications/Handbook/Article s/fisher_handbookII.pdf (Erişim Tarihi: 23.10.2020).

Güleç, C. (2015). "Nagorno-Karabakh Dispute: Why Intractable Conflict for Armenia?", Güvenlik Stratejileri Dergisi, 11(22), 1-31.

Hopmann P. T. (2013). Minsk Group Mediation of the Nagorno-Karabakh Conflict: Power, Interest and Identity, https://papers.ssrn.com/sol3/papers.cfm?abstract_id=2300148 (Erişim Tarihi: 20.04.2020).

İşyar, G. (2004). Bölgesel ve Global Güvenlik Çıkarları Bağlamında Sovyet-Rus Dış Politikaları ve Karabağ Sorunu, Bursa: Alfa Aktüel Yayınları.

Klever, E. (2013). "The Nagorno-Karabakh conflict between Armenia and Azerbaijan: An overview of the current situation" https://europeanmovement.eu/wpcontent/uploads/2015/05/2013.09-Current-situation-Nagorno-Karabakh.pdf (Erişim Tarihi: 19.04.2020).

Kocharyan S. (2016). Why Is The Nagorno-Karabakh Conflict St1ll Not Resolved?, https://www.mfa.am/filemanager/Statics/A_nkr_en.pdf (Erişim Tarihi: 12.04.2020).

Köremezli, İ. (2011). “ABD’nin Güney Kafkasya Politikası”, Cenap Çakmak vd (ed.), Yakın Dönem ABD Dış Politikası :Teori ve Pratik içinde (255-277), Ankara: Nobel Yayınları. 
Lis M. (2016). No Peace In Nagorno-Karabakh: Economic And Political Incentives For The Perpetuatıon Of The Azerbaijani-Armenian Conflict, Yüksek Lisans Tezi, Lieben, Hollanda https://openaccess.leidenuniv.nl/bitstream/handle/1887/44244/MLis_Master_Thesis\%2 Ofinal.pdf?sequence=1 (Erişim Tarihi: 27.04.2020).

Makas, Z. A. (1990). Azerbaycan'ın Tarihi ve Kültürel Coğrafyası, Ankara: Kök Yayınları.

Maresca, J. (1996). Lost Opportunities in Negotiating the Conflict over Nagorno Karabakh, International Negotiation, 1(3), 471-479.

Melander, E. (2001). "The Nagorno-Karabakh Conflict Revisited Was the War Inevitable?", Journal of Cold War Studies, 3(2), 48-75.

Milliyet. (2020). “Çetin- Kozirev İşbirliği Yürür mü?”, http://gazetearsivi.milliyet.com.tr/Rusya\%20Gurcistan\%20iliskileri/ (Erişim Tarihi:10.11.2020).

Milliyet. (10.11.2020). https://www.milliyet.com.tr/galeri/son-dakika-ilkfotograflar-rus-tanklari-daglik-karabaga-6350713/15 (Erişim Tarihi: 10.11.2020).

Moore, C. W. (1996). The Mediation Process: Political Strategies for Resolving Conflict (2.Bask1), San Francisco: Jossey - Bass.

Mosashvili, G. (June 2019). Conflict in Montainous Karabakh, Conference Paper.

Özy1lmaz, V. (2013). “Geçmişten Günümüze Dağlık Karabağ”, Gazi Üniversitesi İktisadi ve İdari Bilimler Fakültesi Dergisi, 15(22), 191-208.

Pokalova, E. (2014). Conflict Resolution in Frozen Conflicts: Timing in NagornoKarabakh, Journal of Balkan and Near Eastern Studies, 17 (1), 68-85.

Sienrukos H. (2006). O11, Democracy And The Globalization Of The Nagorno Karabakh Conflıct, Yüksek Lisans Tezi, https://sites.tufts.edu/fletcherrussia/files/2018/09/2007-Hilary-Sienrukos-OilDemocracy-and-the-Globalization-of-the-Nagorno-Karabakh-Conflict.pdf (Erişim Tarihi: 26.04.2020).

Taşkıran, C. (1995). Geçmişten Günümüze Karabă̆ Meselesi, Ankara: Genel Kurmay Basım Evi.

Taşkıran, C. (2001). Ermeni - Azeri Çatışması, Avrasya Dosyası, 2(4), 122-137.

Vaserman, A. \& Ginat, R. (1994). "National, Territorial or Religious Conflict? The Case of Nagorno Karabakh", Studies in Conflict and Terrorism, 17(4), 345-362. 
Wall, J. A. \& Lynn, J. A. (1993). Mediation: A Current Review. The Journal of Conflict Resolution, 37(1),160-194.

Wallensteen, P. \& Svensson, I. (2014). Talking Peace: International Mediation in Armed Conflicts, Journal of Peace Research Anniversary Special Issue, 51(2), 315-327.

Wasington Post, (2020). Cease-fire in Nagorno-Karabakh provokes protests in Armenia, celebrations in

Azerbaijan, https://www.washingtonpost.com/world/europe/nagorno-karabakh-ceasefire-armeniarussia-azerbaijan/2020/11/10/b1b9bcc0-231b-11eb-9c4a-0dc6242c4814_story.html (Erişim Tarihi: 10.11.2020).

Y1lmaz, M. E. (2006). "Third-Party Intervention in International Conflicts: Peacekeeping and Peacemaking in the Post-Cold War Era”, Uluslararası İlişkiler Dergisi, 3(11), 25-44.

Y1lmaz, M. E. (2018). Uyuşmazlık Analizi ve Çözümü: İnsan Uyuşmazlıklarının Kaynakları ve Çözüm Paradigmaları (2. Baskı), Bursa: Dora Yayıncılık.

Żakowska M. (2014). "Mediation In Armed Conflict," Securiyt and Defence Quarterly”, 17(4), 74-99.

Zartman, W. I \& Touval, S. (1985). International Mediation:Conflict Resolution and Power Politics, Journal of Social Issues, 42(2), 27-45.

Zartman, W. I \& Touval, S. (1996). International Mediation in the Post Cold War Era: Sources of and Responses To International Conflict, Chester A. Crocker vd, (edt) Managıng Global Chaos içinde (445-463), Washington DC: US Instıtute of Peace.

Zartman, W. I. \& Soto, A. (2010). Timing Mediation Initiative, US Institute of Peace, Washingtfon DC.

Zartman, W. I. (2015). Mediation: Ripeness and its Challenges in the Middle East, International Negotiation, 20(3), 479-493.

Ayten Qurbanova ile 07.07.2020 tarihinde yapılan röportaj.

Ayten Mehmed ile 07.07.2020 tarihinde yapılan röportaj.

Rövşen Hatemov ile 07.07.2020 tarihinde yapılan röportaj.

Sevinç Ruintan ile 14.07.2020 tarihinde yapılan röportaj.

Afet Qulaliyeva ile 14.07.2020 tarihinde yapılan röportaj.

Senuber İsmailova ile 14.07.2020 tarihinde yapılan röportaj.

Faik Aliekberov ile 14.07.2020 tarihinde yapılan röportaj.

Saida Quliyeva ile 14.07.2020 tarihinde yapılan röportaj. 
Giresun Üniversitesi İktisadi ve İdari Bilimler Dergisi, 2021, 7(1): 162-191 Giresun University Journal of Economics and Administrative Sciences, 2021, 7(1): 162-191 Araştırma Makalesi, DOI: 10.46849/guiibd.863631

Eldar Jafarov ile 14.07.2020 tarihinde yapılan röportaj.

İqbal Agayev ile 14.07.2020 tarihinde yapılan röportaj.

Kemale Ruintan ile 14.07.2020 tarihinde yapılan röportaj. 